\title{
Experimental determination with EPR-methods of dose loads on local population in inhabited localities adjacent to the tailing pond "Koshkar- ata" (Kazakhstan)
}

\author{
Kairat Kuterbekov ${ }^{1, *}$, Nurllah Sadykov ${ }^{2}$, Kassym $_{\text {Zhumadilov }}{ }^{1}$, Rano Nurgaliyeva $^{1}$, \\ Aset Kabyshev ${ }^{1}$, Erbolat Abseitov ${ }^{1}$, and Askar Kurmanzhanov ${ }^{1}$ \\ ${ }^{1}$ L.N. Gumilyov Eurasian National University, Astana, Kazakhstan \\ ${ }^{2}$ Sh. Esenov Caspian University of Technology and Engineering, Aktau, Kazakhstan
}

\begin{abstract}
EPR study of TE from teeth donors in KOSHKAR-ATA region. During the first year we received22 tooth samples from local people in KOSHKAR-ATA region; the teeth were removed by dentists in accordance with their medical prescriptions. Obtained data showed that radiation signal in the analyzed samples corresponds to doses not exceeding $0.3 \mathrm{~Gy}$; only one sample carriers the signal of $(0.35 \pm 0.15) \mathrm{Gy}$.
\end{abstract}

\section{Introduction}

EPR method was chosen as a basic one forexperimental determination of dose loads on local population.It is known that EPR-dosymetry of teeth enamel (TE) has been recommended by IAEA and WHO as a basic method for assessment of various-type radiation impacts on population. High precision and reliability of the method has been proved by inter-laboratory experiments "Intercomparison 1, 2, 3" specially performed under the aegis of IAEA and "Intercomparison 4" performed in 2005-2006 initiated by the University of Hiroshima. Almost all leading laboratories allover the world took part in these experiments.

Considerable preliminary work was performed for metrological and legal provisions: certification of a spectrometer, certification of a laboratory for the right to run EPRdosimetry of TE in Kazakhstan, participation of the laboratory in international comparison experiments.

Direct measurements of doses are vital since in many cases there are sets of unfavorable (climatic, social, moral) factors that, like radiation, may negatively influence public health and available indirect dose assessments are quite different for many authors. It is also important that information provided by EPR dose reconstruction may influence on conclusions of experts regarding radiological situation in various regions of the country.

It should be mentioned that in the field of EPR-dosimetry there is no conventional internationally accepted standard to set requirements to equipment, instruments, materials,

\footnotetext{
*Corresponding author: kkuterbekov@gmail.com
} 
sample preparation methods, spectrum registration and calibration conditions, algorithms for their processing, etc. There are national standards available, for instance, Russian State Standard ГОСТ P 22.3.04-96 accepted in Kazakhstan, but by now this standard became obsolete to considerable extent.

Calibration of $\gamma$-source dose rate. Results considerably depend on calibration of dose rate generated by the $\gamma$-source with respect to a standard source of the IAEA Laboratory of Dosimetry. In the beginning of 2004 there was calibrated a ${ }^{137} \mathrm{Cs} \gamma$-source of INP laboratory within IAEA project IDAS 2004. In accordance with the procedure, three alanine (from IAEA kit) dosimeters were irradiated with a dose exceeding $100 \mathrm{~Gy}$ and the forth one served for estimations of background radiation.

Adjustment of the method for TE sample preparation to teeth samples of population from inhabited localities near KOSHKAR-ATA.To gain pure teeth enamel we used IS method with treatment in alkaline solution that is quite widely used with various modifications in many countries since the method intensifies TE extraction. But still possible influence of such treatment on EPR-radiation signal has not been studied in details. We have employed a method that involves additional irradiation. Chosen 4 samples of lowcaries teeth were additionally irradiated with quite high dose of about 5 Gy to assure clear registration of radiation signal by EPR, and then split up into halves. One of the halves of each tooth was treated with IS in presence of $\mathrm{NaOH}$ or $\mathrm{KOH}$ of various concentrations during different times for different samples, and then dentine was removed. In the second halves dentine was removed using only mechanical methods (diamond cut). After that registered EPR dosimetric signals for two methods were compared.

In the experiments [1] it was shown that treatment in $5 \mathrm{~N}$ alkali solution up to 6-8 hours do not influence practically the magnitude of radiation EPR signal from carbonate radicals $\mathrm{CO}_{2}^{-}$; at this it facilitates dentine removal. Long-term treatment (for 24-28 hours and more) softens dentine, but significantly reduces EPR signal (to $4-50 \%$ ); at this $\mathrm{KOH}$ acts more effectively than $\mathrm{NaOH}$.

\section{KOSHKAR-ATA region}

EPR study of TE from teeth donors in KOSHKAR-ATA region. During the first year we received 22 tooth samples from local people in KOSHKAR-ATA region; the teeth were removed by dentists in accordance with their medical prescriptions.

First set of four teeth was contaminated with non-removable paramagnetic admixture that shows wide intensive line what prevents from determination of informative radiation signal.

Nevertheless, we succeeded to find a technique enabling us to assess doses in those samples; the results are available in Table 1.

EPR study of TE from teeth donors in KOSHKAR-ATA region. During the first year we received 22 tooth samples from local people in KOSHKAR-ATA region; the teeth were removed by dentists in accordance with their medical prescriptions.

First set of four teeth was contaminated with non-removable paramagnetic admixture that shows wide intensive line what prevents from determination of informative radiation signal.

Nevertheless, we succeeded to find a technique enabling us to assess doses in those samples; the results are available in Table 1. 
Table 1. Doses determined in the first set of taken teeth.

\begin{tabular}{|c|c|c|c|c|c|c|c|c|c|}
\hline $\begin{array}{c}\text { Sample } \\
\text { No. }\end{array}$ & Name, ID & $\begin{array}{c}\text { Age of } \\
\text { donor, }\end{array}$ & $\begin{array}{c}\text { No. of } \\
\text { tooth }\end{array}$ & $\begin{array}{c}\text { Weig } \\
\text { ht } \mathbf{~ m g}\end{array}$ & $\begin{array}{c}\text { Numbe } \\
\text { r of } \\
\text { registra } \\
\text { tions }\end{array}$ & $\begin{array}{c}\text { Dos } \\
\mathbf{e} \\
\mathbf{m G} \\
\mathbf{y}\end{array}$ & $\begin{array}{c}\text { Number } \\
\text { of assess } \\
\text { ments }\end{array}$ & $\begin{array}{c}\text { Averag } \\
\text { e, } \\
\text { Relative } \\
\text { Error }\end{array}$ & $\begin{array}{c}\text { Necessity of } \\
\text { irrad. }\end{array}$ \\
\hline 1 & 2 & 3 & 4 & 5 & 6 & 7 & 8 & 9 & 10 \\
\hline 1 & $\begin{array}{c}\text { Rysbayev } \\
, 63201\end{array}$ & 1932 & 5 & 104.4 & 5 & $\begin{array}{c}0.15 \\
\mathrm{mG} \\
\mathrm{y}\end{array}$ & 6 & $\pm 20.3 \%$ & $\begin{array}{c}\text { recommend } \\
\text { ed }\end{array}$ \\
\hline 2 & $\begin{array}{c}\text { Reshetnik } \\
\text { ov, 63202 }\end{array}$ & 1954 & 5 & 85.9 & 4 & $\begin{array}{c}\text { Not } \\
\text { defi } \\
\text { ned }\end{array}$ & 4 & $>100 \%$ & necessary \\
\hline 3 & $\begin{array}{c}\text { Makholov } \\
\text { a*,63003 } \\
63004\end{array}$ & 1960 & $\begin{array}{l}1 \text { left, } \\
\text { right } \\
\text { incisor }\end{array}$ & $\begin{array}{c}46.6 \\
54.6\end{array}$ & $\begin{array}{c}2 \text {-for } \\
\text { frontal } \\
\text { lingual }\end{array}$ & $\begin{array}{c}0.90 \\
0.04\end{array}$ & 2 & $\pm 4 \%$ & Not \\
\hline 4 & $\begin{array}{c}\text { Musayeva } \\
63005\end{array}$ & 1952 & 7 & 70.4 & 5 & 0.30 & & $\pm 40 \%$ & necessary \\
\hline
\end{tabular}

Three tooth were found unsuitable for EPR-analysis due to considerable damage with caries and small amount of TE on them (required to analysis value is $50-10 \mathrm{mg}$ ). All other samples were taken in accordance with presented above method.

Obtained data showed that radiation signal in the analyzed samples corresponds to doses not exceeding $0.3 \mathrm{~Gy}$; only one sample carriers the signal of $0.35 \pm 0.15 \mathrm{~Gy}$.

Characteristics of samples and qualitative results of measurements for several of them are presented in Table 2 and Table 3.

Table 2. Doses determined for some of samples in the $2^{\text {nd }}$ set.

\begin{tabular}{|c|c|c|c|c|c|c|}
\hline $\begin{array}{c}\text { Sample } \\
\text { number }\end{array}$ & $\mathbf{6 3 2 1 1}$ & $\mathbf{6 3 2 1 2}$ & $\mathbf{6 3 2 1 4}$ & $\mathbf{6 3 2 1 5}$ & $\mathbf{6 3 2 1 6}$ & $\mathbf{6 3 2 1 8}$ \\
\hline $\begin{array}{c}\text { Name of } \\
\text { donor }\end{array}$ & $\begin{array}{c}\text { Turekhanov } \\
\text { S. }\end{array}$ & $\begin{array}{c}\text { Masimova } \\
\text { Zh. }\end{array}$ & $\begin{array}{c}\text { Dudukalov } \\
\text { V. }\end{array}$ & $\begin{array}{c}\text { Belyakova } \\
\text { S. }\end{array}$ & $\begin{array}{c}\text { Stelmakh } \\
\text { S. }\end{array}$ & $\begin{array}{c}\text { Stobva } \\
\text { A.A. }\end{array}$ \\
\hline $\begin{array}{c}\text { Age of } \\
\text { donor, } \\
\text { years }\end{array}$ & 46 & 34 & 53 & 63 & 57 & 37 \\
\hline $\begin{array}{c}\text { Dose } \\
\text { estimatio } \\
\text { n, Gy }\end{array}$ & $<0.3$ & $<0.3$ & $<0.3$ & $0.35 \pm 0.15$ & $0.3 \pm 0.15$ & $<0.3$ \\
\hline
\end{tabular}

One may conditionally compare these data with calculated radiation contamination with plutonium. Let us suppose there is plutonium in soil in amounts $1 \mathrm{kBq} / \mathrm{kg}$ (i.e. quite heavy contamination) and all $1 \mathrm{~kg}$ has been intaken into a human body. Let us calculate maximal number of defects (in this case - free radicals) during a year due to irradiation from plutonium. Energy of an alpha-particle is approximately $5 \cdot 10^{6} \mathrm{eV}$ and, if energy per a bond is $50 \mathrm{eV}$, one $\alpha$-particle produces $\sim 1 \cdot 10^{5}$ defects. During a year $1 \mathrm{kBq}$ of $\mathrm{Pu}$ in a body will generate $1 \cdot 10^{5} \cdot 3 \cdot 10^{7} \cdot 10^{3}$ what comprises $\sim 3 \cdot 10^{15}$ defects $/ \mathrm{kg}$.

From Table 3 one can see that we deal with the values of the same order of magnitude and, keeping in mind that their direct comparison is not scientifically correct, the obtained data indicate the necessity of thorough investigation. 
Table 3. Information on teeth donors from Western Kazakhstan dose accumulated according to EPR-dosymetry data.

\begin{tabular}{|c|c|c|c|c|c|c|c|c|c|}
\hline No. & $\begin{array}{c}\text { Sample } \\
\text { No. }\end{array}$ & $\begin{array}{l}\text { Donor } \\
\text { name }\end{array}$ & $\begin{array}{l}\text { Birth } \\
\text { year }\end{array}$ & Address & $\begin{array}{l}\text { Years of } \\
\text { current } \\
\text { residence }\end{array}$ & $\begin{array}{c}\text { Toot, } \\
\text { h }\end{array}$ & $\begin{array}{c}\text { Sample } \\
\text { weight, } \\
\text { mg }\end{array}$ & $\begin{array}{c}\text { Irradiat } \\
\text { ion } \\
\text { dose, } \\
\text { mGy }\end{array}$ & Notes \\
\hline 1 & 63206 & $\begin{array}{l}\text { Makha } \\
\text { nbetov } \\
\text { A. }\end{array}$ & 1952 & $\begin{array}{c}\text { v. } \\
\text { Yeraliev } \\
\text { o }\end{array}$ & 50 & $\begin{array}{l}1 \text { low } \\
\text { right }\end{array}$ & 60,1 & $<170$ & $\begin{array}{c}5 \\
\text { measu } \\
\text { remen } \\
\text { ts } \\
\end{array}$ \\
\hline 2 & 63209 & $\begin{array}{l}\text { Aituar } \\
\text { ovZh. }\end{array}$ & 1960 & $\begin{array}{c}\mathrm{v} . \\
\text { Priozerni } \\
\mathrm{y}\end{array}$ & 20 & $\begin{array}{l}1 \text { low } \\
\text { right. }\end{array}$ & 56,0 & $<180$ & \\
\hline 3 & 63211 & $\begin{array}{c}\text { Turekh } \\
\text { anov } \\
\text { S. }\end{array}$ & 1957 & $\begin{array}{c}\mathrm{v} . \\
\text { Akshuku } \\
\mathrm{r}\end{array}$ & 46 & $\begin{array}{c}5 \\
\text { upper } \\
\text { left } \\
\end{array}$ & 28,2 & $<355$ & \\
\hline 4 & 63212 & $\begin{array}{l}\text { Masim } \\
\text { ovaZh. }\end{array}$ & 1969 & $27-10-89$ & 15 & $\begin{array}{c}5 \\
\text { upper } \\
\text { right }\end{array}$ & 56.7 & $\begin{array}{c}1640 \pm 9 \\
\%\end{array}$ & \\
\hline 5 & 63213 & $\begin{array}{c}\text { Turzha } \\
\text { kova } \\
\text { B. }\end{array}$ & 1937 & $\begin{array}{c}\text { Kt.Tyub } \\
\mathrm{e}\end{array}$ & 20 & $\begin{array}{l}2 \text { low } \\
\text { right }\end{array}$ & 7.2 & & $\begin{array}{c}\text { Not } \\
\text { evalua } \\
\text { ted }\end{array}$ \\
\hline 6 & 63214 & $\begin{array}{l}\text { Duduk } \\
\text { alov V. }\end{array}$ & 1950 & $11-6^{a}-65$ & 30 & $\begin{array}{l}6 \text { low } \\
\text { right }\end{array}$ & 91.5 & $\begin{array}{c}2000 \pm 3 \\
\%\end{array}$ & \\
\hline 7 & 63215 & $\begin{array}{l}\text { Belyak } \\
\text { ova S. }\end{array}$ & 1940 & $7-5-105$ & 30 & $\begin{array}{c}6 \\
\text { upper } \\
\text { right }\end{array}$ & 61.4 & $<170$ & \\
\hline 8 & 63216 & $\begin{array}{l}\text { Stelma } \\
\text { kh S. }\end{array}$ & 1946 & $15-5-10$ & 25 & $\begin{array}{l}3 \text { low } \\
\text { right }\end{array}$ & 71.1 & $<140$ & $\begin{array}{c}6 \\
\text { measu } \\
\text { remen } \\
\text { ts }\end{array}$ \\
\hline 9 & 63217 & $\begin{array}{l}\text { Tulesh } \\
\text { ovaM. }\end{array}$ & 1949 & $4-65-2$ & 15 & $\begin{array}{l}5 \text { low } \\
\text { right }\end{array}$ & 6.8 & & $\begin{array}{c}\text { Not } \\
\text { evalua } \\
\text { ted }\end{array}$ \\
\hline 10 & 63218 & $\begin{array}{l}\text { Stobva } \\
\text { A.A. }\end{array}$ & 1966 & $14-20-67$ & 15 & $\begin{array}{l}7 \text { low } \\
\text { right }\end{array}$ & 94.4 & $<105$ & $\begin{array}{c}5 \\
\text { measu } \\
\text { remen } \\
\text { ts }\end{array}$ \\
\hline 11 & 63219 & $\begin{array}{c}\text { Bazarb } \\
\text { ayev }\end{array}$ & 1963 & $\begin{array}{c}11-27- \\
118\end{array}$ & 12 & $\begin{array}{c}7 \\
\text { upper } \\
\text { left }\end{array}$ & 109.2 & $<92$ & \\
\hline 12 & 63220 & $\begin{array}{c}\text { Kazak } \\
\text { h N. }\end{array}$ & 1963 & $28-25-19$ & 11 & $\begin{array}{c}7 \\
\text { upper } \\
\text { left } \\
\end{array}$ & 137.3 & $<75$ & \\
\hline 13 & 63221 & $\begin{array}{l}\text { Basbay } \\
\text { ev N. }\end{array}$ & 1964 & $\begin{array}{c}\mathrm{v} . \\
\text { Akshuku } \\
\mathrm{r}\end{array}$ & 12 & $\begin{array}{l}2 \text { low } \\
\text { right }\end{array}$ & 81.5 & $480 \pm$ & \\
\hline 14 & 63222 & $\begin{array}{l}\text { Naresh } \\
\text { ov S. }\end{array}$ & 1958 & $3^{\mathrm{a}-5-7}$ & 15 & $\begin{array}{c}6 \\
\text { upper } \\
\text { right }\end{array}$ & 125.3 & $<80$ & \\
\hline 15 & 63223 & $\begin{array}{l}\text { Smirno } \\
\text { v T. }\end{array}$ & 1954 & $4-27-18$ & 17 & $\begin{array}{c}6 \\
\text { upper } \\
\text { left }\end{array}$ & 200 & $<50$ & \\
\hline
\end{tabular}


Measurements were made at room temperature, frequency $9.827 \mathrm{GHz}$, SHF - power $25 \mathrm{~mW}$, field modulation frequency $100 \mathrm{\kappa Hz}$, field modulation amplitude $4.85 \mathrm{G}$, field sweep $96.4 \mathrm{G}$, sweep time $21 \mathrm{~s}$, time constant $41 \mathrm{~ms}$, amplification coefficient $10^{5}$, field resolution 1024 points, resolution of analog-digital conversion - 13 bit. 50 savings were made for each spectrum registration. The spectrum was usually registered three times and every time the sample was shaken (to get better averaging of orientation of crystallographic axes with respect to the constant field).

\section{Acknowledgments}

This work was supported by the Ministry of Education and Science of the Republic of Kazakhstan within the program of funding research activities through grants for 2015-2017 «Development of Hydrogen Energy and Technology in the Republic of Kazakhstan».

\section{References}

1. K.A. Kuterbekov, et al. $16^{\text {th }}$ Radiochemical Conference-2010, Marianske Lenzne, Czech Republic, CHLSAC 104(S), 181 (2010) 